\title{
An Impressive Scope of Topics
}

Sandra Bermann \& Catherine Porter, eds. 2014. A Companion to Translation Studies. West Sussex: John Wiley and Sons, Ltd. 654 pp. ISBN: 978-0-470-67189-4

DOI: 10.21066/carcl.libri.2017-06(01).0006

A Companion to Translation Studies, edited by Sandra Bermann and Catherine Porter, belongs to a growing number of recently published compendium-type works in translation studies. For example, Jeremy Munday's The Routledge Companion to Translation Studies (2009), The Oxford Handbook of Translation Studies (2011), edited by Kirsten Malmkjær and Kevin Windle, Routledge Encyclopedia of Translation Studies, first published in 1998, and issued in an updated version edited by Mona Baker and Gabriela Saldanha in 2009, Lawrence Venuti's The Translation Studies Reader, first published in 2000 and now in its third edition (2012), A Companion to Translation Studies, edited by Piotr Kuhiwczak and Karin Littau (2007), to name just a few. The relatively frequent recent production of such large compendia is an indication of the need for translation studies scholars to systematise the current state of affairs in this fast-growing field, characterised by a multiplicity of approaches, methodologies and research topics. The multiplicity and heterogeneity of approaches, methodologies and paradigms are not surprising in this "vastly complex field with many far-reaching ramifications", as described by Susan Bassnett in Translation Studies (1991: 1), which has since its inception in the 1960s and 1970s attracted a large number of scholars from diverse humanistic and social sciences backgrounds.

A Companion to Translation Studies comprises forty-five chapters taking up 612 of its 654 pages. The sheer size of the book is matched by an impressive scope of topics ranging from machine translation and localisation to self-translation, pseudotranslation and intralingual translation. However, we should point out that in this companion there is a clear prevalence of comparative literature focus, which comes as no surprise given the academic and research background of its editors. Sandra Bermann is the Cotsen Professor of the Humanities and Professor of Comparative Literature at Princeton University. Her research and writing both focus on poetry, translation, and literary theory. She served as President of the American Comparative Literature Association from 2007 to 2009. Catherine Porter is currently professor emerita of French at the State University of New York at Cortland. Her professional biography includes a large number of translations of scholarly works from eminent French theoreticians/philosophers, such as Jacques Derrida and Michel Foucault.

The book is divided into three large parts: Part I - "Approaches to Translation", Part II - "Translation in a Global Context", and Part III - "Genres of Translation", which are further divided into subsections. The book contains an index and each chapter is accompanied with a Notes and References section and an elaborate Further Reading list. In the Introduction, the editors list an impressively big number of research questions tackled in the collected essays: the role translation has played in specific political and religious structures in the past and the role it plays today, the methods of studying oral translations, the role translation may play in the performativity of gendered and "queer" identities, the ethics of translation, the role of various agents in the production of a translation. 
With regard to the complex roles of translation, particular emphasis is placed on colonial and postcolonial situations ("What Is Special about Postcolonial Translation" by Ben Conisbee Baer, "Postcolonial Issues in Translation: The African Context" by Kathryn Batchelor and "Postcolonial Issues: Translating Testimony, Arbitrating Justice" by Christi A. Merrill, and "Translating the Sacred: Colonial Constructions and Postcolonial Perspectives" by Hephzibah Israel). Indeed, one of the main strengths of this Companion is its tendency to move from the long-dominant Eurocentric perspective. Thus, Bermann and Porter emphasise in the Introduction that "translation theory is increasingly attentive to geolinguistic diversity" (10) and conclude: "Particularly conscious of the widening context of translation studies, this Companion attempts to situate the field in a broad geolinguistic and historical space" (10). This striving is evident from a large number of essays concerned with translation practices in Asia ("Translation as Intercultural Communication: Views from the Chinese Discourse on Translation" by Martha P.Y. Cheung, "Worlds Without Translation: Premodern East Asia and the Power of Character Strips" by Wiebke Denecke, "A Crisis of Translation: Early European Encounters with Japan" by Valerie Henitiuk, "Translating Japanese into Japanese: Bibliographic Translation from Woodblock to Moveable Type" by Michael Emmerich), and Africa ("Postcolonial Issues in Translation: The African Context" by Kathryn Batchelor).

Contributions in Part I (“Approaches to Translation") are divided into three categories: "Histories and Theories", "Methodologies", and "Technologies". Openness to new research topics and areas is clearly demonstrated in the organisation of Part I, where contributions on histories and theories and methodologies (well-established research topics) are accompanied with a newly emergent domain that affects both the practice of translators and the theoretical considerations of translational phenomena: technologies.

Owing to the scope of the Companion, both in terms of the number of chapters and the breadth of topics covered, it would be unrealistic to attempt to provide a thorough overview of all chapters. It should also be noted that not all contributions provide equally comprehensive and theoretically founded insights. Some of them do not go beyond interesting case studies, lacking broader perspective. Therefore, we focus rather on those chapters that might be particularly inspiring for students and scholars working in the Croatian context.

In "The Changing Landscape of Translation and Interpreting Studies", Mona Baker focuses on some concerns that gained particular attention in the 1990 s and the early $21^{\text {st }}$ century, such as the position of minority languages in the globalised world, in which, as Michael Cronin (2003) points out in Translation and Globalization, "all other languages than English have become minority languages" (17). Baker points to the research topics arising from the hegemonic position of English in the globalised world, such as the dominant position of English in the publishing industry and the media. On the other hand, resistance to the globalised conglomerates has opened new avenues for research. As for future directions, Baker claims that the issues of ethics and trust are gaining attention and are expected to occupy a more central position within the discipline.

A particularly interesting chapter in the "Methodologies" is "The Sociology of Translation" by Gisèle Sapiro (France), Professor of Sociology at the École des hautes études en sciences sociales and Research Director at the CESSP (Centre européen de sociologie et de science politique). An overview of the well-trodden research paths within 
the domain of the sociology of translation (the sociology of professions, the sociology of culture, the study of international exchanges, social functions and fields) is supplemented with suggestions for bringing an innovative perspective to the sociological approach to translation. For example, the familiar fact that the observation of translation flows among languages confirms the dominance of the English language as a source language in the era of globalisation is cast in a different light when "the social functions of translation in different fields" are taken into account (86). German dominance over English in the translations of philosophical works, as stated earlier by Gisèle Sapiro in her paper "Translation and the Field of Publishing: A Commentary on Pierre Bourdieu's 'A Conservative Revolution in Publishing' from a Translation Perspective" (2008), indicates that the social functions of translation in different fields influence the choice of the source language. The application of Bourdieuesque analysis of the "field of publishing" divided into the pole of large-scale market-ruled production and the pole of small-scale production, informed by aesthetic, nation-promoting and intellectual considerations brings about useful insights into the generally accepted notions of asymmetrical relations of cultural exchange: linguistic diversity is very high at the pole of small-scale circulation. This leads Sapiro to conclude: "Though globalization has reinforced the economic constraints that the pole of large-scale production imposes upon the pole of small-scale production, nation-states still play a crucial role in the world market of translation by providing financial aid for the 'exportation' of national book production in translation and, in some cases, like that of France, also for the importation of foreign literary and scholarly works" (88). Another potentially productive suggestion is a call to undertake further research "in order to bridge the gap between the sociology of translation and the study of norms and practices of translation" (91).

Şehnaz Tahir Gürçağlar's essay "Pseudotranslation on the Margin of Fact and Fiction" brings up the topic of pseudotranslations, i.e. "texts which have been presented as translations with no corresponding source texts in other languages ever having existed", as defined by Gideon Toury in Descriptive Translation Studies and Beyond (1995: 40). The essay provides an interesting case study of a Swedish pseudotranslation, titled Vinden vänder vid Bosporen, En Enkel Turks Dagbok, and its German and French editions by Hanna Hindbeck, which reveals the multiple motives behind pseudotranslations. Hindbeck's novel, which pretended to be the autobiography of a Turkish police officer in the final years of the Ottoman Empire, was published more or less simultaneously in a German and a Swedish version in 1935. It was followed by a French translation and enjoyed popularity, while its status as a pseudotranslation came to light in as late as 2003.

In "Translated Literature and the Role of the Reader", Brian James Baer takes up Barthes' notion of "readerly" texts to apply it to various types of strategies typically developed by readers in authoritative regimes, placing particular emphasis on translated texts. The strategies discussed include "reading between", i.e. constructing alternative interpretations, "reading among", i.e. creating interpretative communities engaged in the unofficial production, circulation, and interpretation of censored works, and "reading against", producing competing or alternative translations of the same source text. With regard to "reading between", Baer quotes concrete examples from Lev Loseff's (1984) study On the Beneficence of Censorship related to censorship in Soviet Russia. Russian translators developed particular strategies in order to build "a system of screens and cues to 
shield 'alternative' interpretations from the censor while encouraging sympathetic readers to make those interpretations". An interesting example is translations by a Russian poet who served in the Gulag and "inserted prison slang into his translations, inscribing his own experience on the textual surface of the translation" (338).

To conclude, A Companion to Translation Studies is a highly valuable recent contribution to the field of translation studies, which provides a broad audience with a comprehensive and excellent overview both of major issues discussed within the discipline and of the most recent trends in research. In addition, as its editors point out, it is conceived as a handbook that will be useful to students, with both theoretical and practical interest in translation, including those interested in translations of children's literature.

Snježana Veselica Majhut

\section{Picturebooks and Little Thinkers}

Mary Roche. 2015. Developing Children's Critical Thinking through Picturebooks. Abingdon: Routledge. 195 pp. ISBN 978-0-415-72768-6

DOI: 10.21066/carcl.libri.2017-06(01).0007

Developing Children's Critical Thinking through Picturebooks provides an interesting insight into how to use picturebooks as a tool for developing critical thinking from a young age. It is a perfect combination of theoretical background and practical advice to help teachers and parents, among others, to think about their own approach to analysing any material to be used with students or children.

The book is written by Mary Roche, an Irish teacher and researcher with a particular interest in critical thinking and literature. It is the result of her lifelong devotion to reading and thinking about reading. Throughout this book, the reader feels her passion and the rich experience she has in this field.

As the author says, the book itself is aimed at classroom teachers, future teachers, literacy students, parents, and all those who are interested in promoting critical thinking and raising it to a higher level from a young age. The language used in the book is easily understood and is therefore accessible to all the previously mentioned audiences. The author herself emphasises that the book does not provide a simple recipe that the reader can follow when analysing picturebooks. However, it guides the reader and provides advice on how to improve "book talk". Many examples from the author's own practice play a crucial role in understanding her approach, and help the reader in improving his or her own practice in this area.

The book is divided into two main sections, a theoretical and practical one, which are sometimes intertwined due to the fact that you simply cannot have one without the other. The book in general is divided into eight equally important chapters.

The introductory part of this book is well organised and provides an enjoyable welcome. It explains why this book was written, briefly describes the relevant experience of the author, and explains in detail the structure of the book. The reader certainly knows what to expect and feels equipped to start.

The first chapter ("Critical thinking and book talk") provides a short outline of what critical thinking is, why it is important, and what is needed to develop it. It also dwells upon 